\title{
Model Pengembangan Pemberdayaan Pengetahuan (Studi pada Perpustakaan Desa Paseban, Kecamatan Kencong, Kabupaten Jember)
}

\author{
Anita Tri Widiyawati \\ Program Studi Ilmu Perpustakaan, Universitas Brawijaya, Malang \\ Email: anitatriw@ub.ac.id
}

\begin{abstract}
This research uses a case study with a qualitative approach. Data collection techniques used are observation, interviews, documentation, audio-visual material (Creswell). Analysis of the data used is Creswell data analysis. The researcher chooses to use qualitative validity and reliability to demonstrate the validity of the data as well as the accuracy of the research results. The results of this study are that the Paseban Village Government has carried out empowerment related to tourism development, BumDes, and through the provision of the internet. However, it is not under the auspices of the village library. The empowerment carried out is partial, not centered on the village library. Paseban Village Government has not fulfilled the three aspects of empowerment, namely a) enabling, b) empowering, and c) protecting. So that there is a need to develop a model of knowledge empowerment in the Paseban Village Library, including: a) enabling, village library as a center of knowledge, village library creates an atmosphere that allows the potential of the community to develop by maximizing the function of the library; b) empowering, strengthening the village library as a center of knowledge, strengthening the village library in creating an atmosphere that enables the potential of the community to develop by maximizing the function of the library with concrete steps ; c) protecting, the village library as a knowledge center establishes an information center that can protect and defend the community in terms of knowledge and information related to the distribution of the results of community innovation.
\end{abstract}

Keywords: Village Library; Knowledge Empowerment; Welfare Literacy

\begin{abstract}
Abstrak
Penelitian ini menggunakan studi kasus dengan pendekatan kualitatif. Teknik pengumpulan data yang digunakan yaitu observasi, wawancara, dokumentasi, materi audio-visual (Creswell). Analisis data yang digunakan adalah analisis data Creswell. Peneliti memilih menggunakan validitas dan realibilitas kualitatif untuk menunjukkan keabsahan data sekaligus keakuratan hasil
\end{abstract}


penelitian. Adapun hasil dari penelitian ini adalah Pemerintah Desa Paseban sudah pernah melaksanakan pemberdayaan terkait pembangunan wisata, BumDes, dan melalui penyediaan internet. Akan tetapi, tidak di bawah naungan perpustakaan desa. Pemberdayaan yang dilakukan bersifat parsial, tidak terpusat pada perpustakaan desa. Pemerintah Desa Paseban belum memenuhi tiga aspek pemberdayaan, yakni a) enabling, b) empowering, dan c) protecting. Sehinggan perlu adanya pengembangan model pemberdayaan pengetahuan pada Perpustakaan Desa Paseban, antara lain: a) enabling, perpustakaan desa sebagai pusat pengetahuan, perpustakaan desa menciptakan suasana yang memungkinkan potensi masyarakat dapat berkembang dengan memaksimalkan fungsi perpustakaan; b) empowering, memperkuat perpustakaan desa sebagai pusat pengetahuan, memperkuat perpustakaan desa dalam menciptakan suasana yang memungkinkan potensi masyarakat dapat berkembang dengan memaksimalkan fungsi perpustakaan dengan langkah-langkah nyata; c) protecting, perpustakaan desa sebagai pusat pengetahuan mendirikan juga pusat informasi yang dapat melindungi dan membela masyarakat dalam hal pengetahuan dan informasi terkait pendistribusian hasil inovasi masyarakat, perpustakaan desa meng-cover segala hal yang dibutuhkan masyarakat dalam mengembangkan literasi kesejahteraan.

Kata kunci: Perpustakaan Desa; Pemberdayaan Pengetahuan; Literasi Kesejahteraan.

\section{A. PENDAHULUAN}

Perpustakaan desa atau juga perpustakaan kelurahan merupakan simpul yang dipandang sangat strategis oleh pemerintah dalam pengembangan dan pemberdayaan masyarakat pada tingkat desa/kelurahan (Darmono, 1:2016). Hal ini dikarenakan, Perpustakaan Desa merupakan garda terdepan dalam mengembangkan potensi desa baik dari sisi masyarakatnya maupun sumber daya alamnya. Akan tetapi pada kenyataanya justru berbanding terbalik dengan kondisi dari kebanyakan perpustakaan desa yang ada di Indonesia. Mayoritas perpustakaan desa tidak mendapatkan perhatian yang maksimal dari Pemerintah Desa dalam pengelolaannya. Masyarakat Desa tidak banyak yang memanfaatkan perpustakaan desa, dikarenakan kurangnya sosialisasi bahkan kebanyakan dari perpustakaan desa tidak memberikan layanan yang rutin. Salah satunya adalah Perpustakaan Desa Paseban, Kecamatan Kencong, Kabupaten Jember.

Berdasarkan kondisi geografis dan masyarakatnya, Desa Paseban mempunyai potensi yang sangat tinggi. Potensi tersebut terdiri atas: 
pertanian, perkebunan, peternakan, perikanan air tawar dan perikanan air laut, pariwisata (wisata Pantai Paseban), hingga budayanya. Potensi ini seringkali tidak disadari oleh masyarakatnya, sehingga tidak dimanfaatkan secara maksimal. Perpustakaan Desa mempunyai peran yang sangat penting dalam memunculkan potensi tersebut melalui pemberian layanan dengan kegiatan pemberdayaan pengetahuan. Pemberdayaan merupakan konsep pembangunan ekonomi yang merangkum nilai-nilai sosial dan mencerminkan paradigma baru dalam pembangunan yang bersifat people centered participatory, empowering and sustainable (Chambers, 1995 dalam Noor, 2011:94). Sedangkan pemberdayaan pengetahuan adalah pemberdayaan yang berfokus pada pencapaian hasil pengetahuan masyarakat. Adapun yang dimaksud dengan pengetahuan di sini adalah hasil dari tahu, dan ini terjadi setelah seseorang melakukan penginderaan terhadap suatu objek tertentu dengan tingkatan yang paling tinggi adalah kemampuan untuk mengevaluasi (Notoatmodjo, 2012). Selama ini, Perpustakaan Desa Paseban hanya berkutat pada penyediaan koleksi tanpa adanya interaksi yang lebih terkait pemberdayaan pengetahuan. Adapun rumusan masalah pada penelitian adalah (1) bagaimanakah kondisi eksisting Perpustakaan Desa Paseban, Kecamatan Kencong, Kabupaten Jember? (2) bagaimanakah pemberdayaan pengetahuan pada Perpustakaan Desa Paseban, Kecamatan Kencong, Kabupaten Jember? (3) bagaimanakah model pengembangan pemberdayaan pengetahuan pada Perpustakaan Desa Paseban, Kecamatan Kencong, Kabupaten Jember? Berdasarkan permasalahan tersebut, maka peneliti tertarik untuk menghasilkan suatu model pengembangan pemberdayaan pengetahuan pada Perpustakaan Desa melalui hasil analisis penelitian. Sehingga judul dari penelitian ini adalah "Model Pengembangan Pemberdayaan Pengetahuan (Studi Kasus pada Perpustakaan Desa Paseban, Kecamatan Kencong, Kabupaten Jember)".

Penelitian ini menggunakan jenis penelitian studi kasus dengan pendekatan kualitatif. Dalam penelitian ini, peneliti memilih tipe studi kasus tunggal (studi dalam-situs) menurut (Creswell,2015: 139). Teknik pengumpulan data pada penelitian ini yaitu observasi, wawancara, dokumentasi, materi audio-visual (Creswell, 2016: 254-266). Analisis data yang digunakan pada penelitian ini adalah analisis data Creswell. 


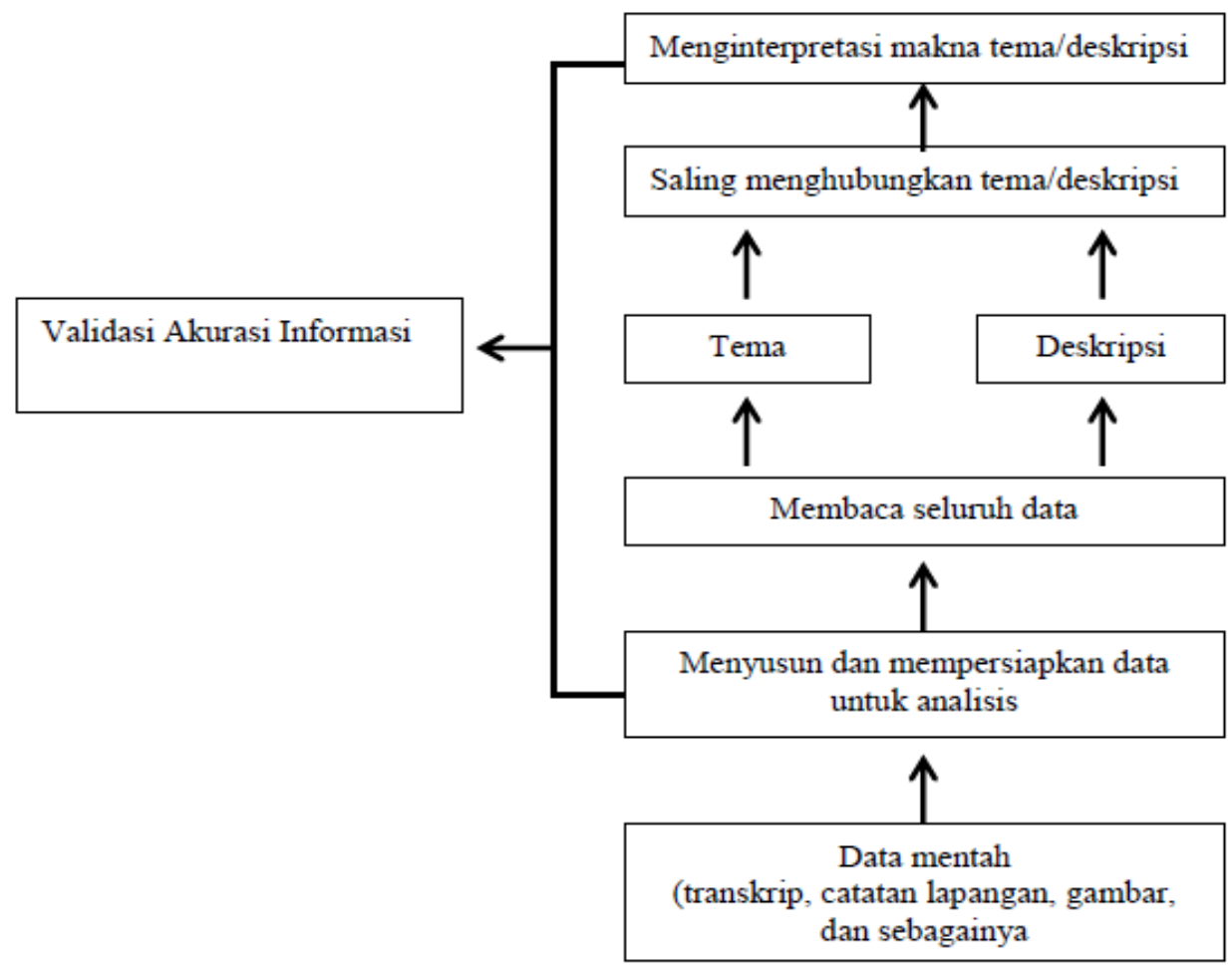

Gambar: sistem analisis data Creswell

Peneliti memilih menggunakan validitas dan realibilitas kualitatif untuk menunjukkan keabsahan data sekaligus keakuratan hasil penelitian yakni validitas kualitatif menurut Gibbs (2007) dalam Creswell (2016: 269).

\section{B. HASIL DAN PEMBAHASAN}

\section{Perpustakaan Desa}

Keberadaan perpustakaan tidak bisa dipisahkan dari tatanan masyarakat (Rahmawati dan Sudarsono 2012 dalam Darmono, 2016:3). Jika ditelaah melalui pendekatan ilmu sosial bahwa lingkup struktur masyarakat banyak menjadi sebuah istilah yang disepakati yaitu suatu sistem atau institusi. Sementara perpustakaan boleh disebut dengan sebuah lembagai informasi sosial yang juga berupa institusi. Perpustakaan memiliki struktur yang telah bertahan sepanjang waktu tertentu di dalam wilayah tertentu.. perpustakaan melakukan interaksi dengan masyarakat yang menggunakannya yang kemudian disebut bagian dari sistem sosial. Perpustakaan adalah interaksi antar anggota masyarakat yang diproduksi dan direproduksi secara 
terus menerus sehingga terpola dan terlihat sebagai kegiatan rutin. Dengan demikian perpustakaan adalah sistem sosial yang mengandung di dalamnya interaksi antarberbagai pihak dan berlangsung terus-menerus melalui tatacara pemanfaatan perpustakaan untuk kegiatan komunikasi pengetahuan membentuk "struktur sosial perpustakaan desa". Perpustakaan desa merupakan jenis perpustakaan umum yang berada di lingkungan desa/kelurahan (Darmono, 2016:1). Sedangkan menurut keputusan menteri dalam negeri dan otonomi daerah nomor 3 tahun 2001, perpustakaan desa adalah Perpustakaan masyarakat sebagai salah satu sarana/media untuk meningkatkan dan mendukung kegiatan pendidikan masyarakat pedesaan, yang merupakan bagian integral dari kegiatan pembangunan desa/kelurahan.

\section{Pengertian Pengetahuan}

Pengetahuan adalah hasil dari tahu, dan ini terjadi setelah seseorang melakukan penginderaan terhadap suatu objek tertentu. Penginderaan yang dilakukan terjadi melalui pancaindera manusia, yakni indera penglihatan, pendengaran, penciuman, rasa, dan raba. Namun meskipun begitu sebagian besar pengetahuan manusia diperoleh melalui indera penglihatan dan pendengaran (mata dan telinga) (Notoatmodjo, 2012).

\section{Tingkat Pengetahuan}

Menurut Notoatmodjo (2012) tedapat 6 tingkat pengetahuan di dalam domain kognitif, yaitu: 1) Tahu (Know), Tahu adalah mengingat kembali memori yang telah ada sebelumnya setelah mengamati sesuatu. 2) Memahami (Comprehension), Memahami adalah suatu kemampuan untuk menjelaskan tentang suatu objek yang diketahui dan diinterpretasikan secara benar. 3) Aplikasi (Aplication), Aplikasi adalah suatu kemampuan untuk mempraktikkan materi yang sudah dipelajari pada kondisi real (sebenarnya). 4) Analisis (Analysis), Analisis adalah kemampuan menjabarkan atau menjelaskan suatu objek atau materi tetapi masih di dalam struktur organisasi tersebut dan masih ada kaitannya satu dengan yang lainnya. 5) Sintesis (Synthesis), Sintesis adalah suatu kemampuan menghubungkan bagianbagian di dalam suatu bentuk keseluruhan yang baru. 6) Evaluasi (Evaluation), Evaluasi adalah pengetahuan untuk melakukan penilaian terhadap suatu materi atau objek. Penilaian ini didasarkan pada suatu kriteria yang ditentukan sendiri, atau menggunakan kriteria-kriteria yang telah ada.

\section{Faktor- faktor yang Mempengaruhi Pengetahuan}

Menurut Budiman dan Riyanto (2013) faktor yang mempengaruhi pengetahuan meliputi : 1) Pendidikan, Pendidikan adalah proses perubahan 
sikap dan perilaku seseorang atau kelompok dan merupakan usaha mendewasakan manusia melalui upaya pengajaran dan pelatihan (Budiman \& Riyanto, 2013). 2) Informasi/ Media Massa, Informasi adalah suatu teknik untuk mengumpulkan, menyiapkan, menyimpan, memanipulasi, mengumumkan, menganalisis dan menyebarkan informasi dengan tujuan tertentu. Informasi diperoleh dari pendidikan formal maupun nonformal dapat memberikan pengaruh jangka pendek sehingga menghasilkan perubahan dan peningkatan pengetahuan. Semakin berkembangnya teknologi menyediakan bermacam-macam media massa sehingga dapat mempengaruhi pengetahuan masyarakat. Informasi mempengaruhi pengetahuan seseorang jika sering mendapatkan informasi tentang suatu pembelajaran maka akan menambah pengetahuan dan wawasannya, sedangkan seseorang yang tidak sering menerima informasi tidak akan menambah pengetahuan dan wawasannya. 3) Sosial, Budaya dan Ekonomi, Tradisi atau budaya seseorang yang dilakukan tanpa penalaran apakah yang dilakukan baik atau buruk akan menambah pengetahuannya walaupun tidak melakukan. Status ekonomi juga akan menentukan tersedianya fasilitas yang dibutuhkan untuk kegiatan tertentu sehingga status ekonomi akan mempengaruhi pengetahuan seseorang. Seseorang yang mempunyai sosial budaya yang baik maka pengetahuannya akan baik tapi jika sosial budayanya kurang baik maka pengetahuannya akan kurang baik. Status ekonomi seseorang mempengaruhi tingkat pengetahuan karena seseorang yang memiliki status ekonomi dibawah rata-rata maka seseorang tersebut akan sulit untuk memenuhi fasilitas yang diperlukan untuk meningkatkan pengetahuan. 4) Lingkungan, Lingkungan mempengaruhi proses masuknya pengetahuan ke dalam individu karena adanya interaksi timbal balik ataupun tidak yang akan direspons sebagai pengetahuan oleh individu. Lingkungan yang baik akan pengetahuan yang didapatkan akan baik tapi jika lingkungan kurang baik maka pengetahuan yang didapat juga akan kurang baik. 5) Pengalaman, Pengalaman dapat diperoleh dari pengalaman orang lain maupun diri sendiri sehingga pengalaman yang sudah diperoleh dapat meningkatkan pengetahuan seseorang. Pengalaman seseorang tentang suatu permasalahan akan membuat orang tersebut mengetahui bagaimana cara menyelesaikan permasalahan dari pengalaman sebelumnya yang telah dialami sehingga pengalaman yang didapat bisa dijadikan sebagai pengetahuan apabila medapatkan masalah yang sama. 6) Usia, Semakin bertambahnya usia maka akan semakin berkembang pula daya tangkap dan pola pikirnya sehingga pengetahuan yang diperoleh juga akan semakin membaik dan bertambah. 


\section{Pemberdayaan}

Pemberdayaan (empowerment) secara etimologis berasal dari kata daya yang berarti kemampuan untuk melakukan sesuatu atau kemampuan bertindak. Mendapat awalan ber- menjadi 'berdaya' artinya berkekuatan, berkemampuan, bertenaga, mempunyai akal (cara dan sebagainya) untuk mengatasi sesuatu (Arifin, 2014:3).

Empowerment (pemberdayaan masyarakat) adalah konsep pembangunan ekonomi yang merangkum nilai-nilai sosial dan mencerminkan paradigma baru dalam pembangunan yang bersifat people centered participatory, empowering and sustainable (Chambers, 1995 dalam Noor, 2011:94). upaya untuk memberdayakan masyarakat (empowering) dapat dikaji dari 3 (tiga) aspek: 1) enabling yaitu menciptakan suasana yang memungkinkan potensi masyarakat dapat berkembang. Asumsinya adalah pemahaman bahwa setiap orang, setiap masyarakat mempunyai potensi yang dapat dikembangkan artinya tidak ada orang atau masyarakat tanpa daya. Pemberdayaan adalah upaya untuk membanguna daya dengan mendorong, memotivasi dan membangkitkan kesadaran akan potensi yang dimiliki masyarakat serta upaya untuk mengembangkannya. 2) empowering yaitu memperkuat potensi yang dimiliki masyarakat melalui langkah-langkah nyata yang menyangkut penyediaan berbagai input dan pembukaan dalam berbagai peluang yang akan membuat masyarakat semakin berdaya. Upaya yang paling pokok dalam empowerment ini adalah meningkatkan taraf pendidikan dan derajat kesehatan serta akses ke dalam sumber-sumber kemajuan ekonomi (modal, teknologi, informasi, lapangan keja, pasar) termasuk pembangunan sarana dan prasarana dasar seperti (irigasi, jalan, listrik, sekolah, layanan kesehatan) yang dapat dijangkau lapisan masyarakat paling bawah yang keberdayannya sangat kurang. Oleh karena itu diperlukan program khusus, karena programprogram umum yang berlaku untuk semua tidak selalu menyentuh kepentingan lapisan masyarakat seperti ini. 3) protecting yaitu melindungi dan membela kepentingan masyarakat lemah. Untuk meningkatkan partisipasi masyarakat dalam proses pengambilan keputusan yang menyangkut diri dan masyarakatnya merupakan unsur penting, sehingga pemberdayaan masyarakat sangat erat hubungannya dengan pementapan, pembudayaan dan pengalaman demokrasi (Friedmann, 1994 dalam Noor, 2011:95).

\section{Pemberdayaan Pengetahuan}

Empowerment (pemberdayaan masyarakat) adalah konsep pembangunan ekonomi yang merangkum nilai-nilai sosial dan mencerminkan 
paradigma baru dalam pembangunan yang bersifat people centered participatory, empowering and sustainable (Chambers, 1995 dalam Noor, 2011:94). Pengetahuan adalah hasil dari tahu, dan ini terjadi setelah seseorang melakukan penginderaan terhadap suatu objek tertentu dengan tingkatan yang paling tinggi adalah kemampuan untuk mengevaluasi (Notoatmodjo, 2012). Sehingga dapat dikatakan bahwa pemberdayaan pengetahuan adalah pemberdayaan masyarakat agar masyarakat memiliki pengetahuan hingga tingkat tertinggi. Sedangkan jika merujuk pada perpustakaan desa, secara sosiologis merupakan sistem sosial yang mengandung di dalamnya interaksi antarberbagai pihak dan berlangsung terus-menerus melalui tata-cara pemanfaatan perpustakaan untuk kegiatan komunikasi pengetahuan membentuk "struktur sosial perpustakaan desa". Sementara itu, berdasarkan parameter yang ada pada SNP 005:2011 terkait Perpustakaan Desa yang menjadi penekanan pada pemberdayaan pengetahuan adalah pada (1) Jam buka perpustakaan, (2) Layanan, dan (3) Sarana layanan.

\section{Analisis}

Kondisi eksisting Perpustakaan Desa Paseban, Kecamatan Kencong, Kabupaten Jember adalah sebagai berikut :

a) Gambaran umum lokasi (bentuk, ukuran dan kondisi fisik)

1) Perpustakaan Desa Paseban berbentuk ruang persegi dengan satu ruangan.

2) Ukuran $=3 \times 4 \mathrm{~m}^{2}$

3) Kondisi fisik = dalam keadaan baik, hanya saja kurang terjaga kebersihannya. Ditemukan sisa rokok di dalam ruangan.

b) Kondisi lingkungan

Kondisi lingkungan Balai Desa Paseban termasuk dalam keadaan baik. Sebelah kanan, kiri, depan, dan belakang merupakan rumah warga. Hal ini termasuk juga dengan kondisi potensi dari Desa Paseban itu sendiri.

c) Batas-batas

Batas-batas perpustakaan :

1) Sebelah kiri ruang sekretariat

2) Sebelah kanan ruang aula 
3) Sebelah depan balai desa, warung, mushola.

4) Rencana: depan perpustakaan akan dijadikan taman baca.

d) Potensi

Potensi Desa paseban cukup beragam mulai dari pertanian, peternakan dan pariwisata. Desa Paseban merupakan salah satu desa yang mempunyai potensi tinggi di Kabupaten Jember. Wilayahnya yang dekat dengat pantai merupakan kelebihan tersendiri yang dapat dijadikan sebagai sumber destinasi wisata dan juga sebagai sumber produksi ikan laut. Selain itu, pada dasarnya Desa Paseban mempunyai potensi yang sangat tinggi di bidang pertanian/sawah, ladang/tegalan, serta perikanan darat/tawar. Di bidang pertanian/sawah dan ladang/tegalan, masyarakat menanam berbagai jenis tanaman yang bervariasi, dari mulai polowijo sampai buah, bahkan umbi-umbian. Sedangkan dari bidang perikanan, untuk perikanan air tawar banyak masyarakat yang membuat tambak-tambak, baik tambak di rumah maupun tambak yang dibangun di area dekat persawahan. Adapun produk perikanan air tawar, antara lain: gurami, lele, mujair, dan banyak lagi. Terdapat pula potensi perikanan air payau.

Berdasarkan potensi tersebut seharusnya masyarakat Desa Paseban bisa memanfaatkan potensi yang dimiliki untuk kemakmuran masyarakat itu sendiri, khususnya dari segi ekonomi. Akan tetapi, pada kenyataannya banyak dari masyarakat Desa Paseban dari pemudanya, ibu rumah tangga, kepala keluarga lebih memilih meninggalkan desa dan merantau untuk menjadi TKI ataupun bekerja di wilayah lain. Masyarakat beralasan bahwa di desa tidak ada yang dapat dihasilkan. Adapun negara sasaran dari masyarakat menjadi TKI adalah Malaysia dan Arab Saudi, sedangkan wilayah di Indonesia yang menjadi sasaran dari masyarakat Desa Paseban untuk bekerja adalah: Kalimantan, Sumatera, Bali, dan Papua. Karena masyarakat Desa Paseban tidak mempunyai kemampuan yang dapat diandalkan, kebanyakan dari mereka menjadi buruh kasar.

Survai awal menunjukkan mayoritas masyarakat Desa Paseban belum mempunyai literasi informasi yang baik bahkan ada beberapa orang yang masih buta huruf, sehingga mereka belum dapat memaksimalkan potensi yang dimiliki dalam pemenuhan kebutuhan sehari-hari. Kurangnya pengetahuan dan informasi bagaimana menjadikan potensi yang dimiliki mempunyai nilai lebih yang dapat menghasilkan pemasukan ekonomi bahkan 
bagaimana mendistribusikan produk yang dihasilkan kepada tengkulak yang tepat menjadi kendala tersendiri. Sehingga jika dilihat dari keadaan situasi di Desa Paseban, maka masyarakat Desa Paseban sangat membutuhkan kemampuan literasi informasi dan perpustakaan komunitas desa yang sekaligus menjadi pusat informasi bagi masyarakat Desa Paseban untuk memaksimalkan potensi yang dimiliki demi kesejahteraan masyarakat itu sendiri.

Tabel : Pemetaan Potensi dan Permasalahan Desa Paseban

\begin{tabular}{|c|c|c|c|}
\hline NO & $\begin{array}{l}\text { NAMA } \\
\text { DUSUN }\end{array}$ & POTENSI & PERMASALAHAN \\
\hline 1 & Bulurejo & $\begin{array}{l}\text { 1. Lahan pertanian } \\
\text { a. Padi } \\
\text { b. Jagung } \\
\text { c. Jeruk } \\
\text { d. Semangka } \\
\text { 2. Peternakan } \\
\text { a. Sapi } \\
\text { b. Kambing } \\
\text { 3. Pariwisata } \\
\text { a. Kuliner laut } \\
\text { b. Wisata pantai } \\
\text { c. Terapi pasir } \\
\text { d. Villa }\end{array}$ & $\begin{array}{l}\text { 1. Akses jalan kurang baik, proporsi } \\
\text { jalan masih makadam, perlu } \\
\text { adanya perbaikan jalan. } \\
\text { 2. masyarakat usia produktif lebih } \\
\text { memilih merantau karena kurang } \\
\text { adanya motivasi terkait } \\
\text { pemberdayaan pemuda yang } \\
\text { berdampak pada proses } \\
\text { pembangunan desa. } \\
\text { 3. Penyakit yang sering dikeluhkan } \\
\text { oleh masyarakat adalah lambung. } \\
\text { 4. Tingkat pendidikan terbanyak } \\
\text { adalah lulusan SMP. } \\
\text { 5otensi pariwisata yang kurang } \\
\text { diperhatikan, terlihat akses jalan } \\
\text { yang kurang baik, sampah di } \\
\text { sekitar pantai yang banyak, hingga } \\
\text { tindakan reboisasi yang kurang. } \\
\text { Nelayan tidak memiliki profesi } \\
\text { sampingan yang melaut tergantung } \\
\text { kondisi alam, hal tersebut } \\
\text { ditambah kepemilikan berstatus } \\
\text { lahan garap harus disewakan dan } \\
\text { kurang adanya bimbingan terkait } \\
\text { pemberdayaan potensi alam. } \\
\text { Banyak ditemukan keong laut } \\
\text { yang bisa dimanfaatkan dalam } \\
\text { bentuk UKM, dengan isi keong } \\
\text { diolah menjadi makanan ringan } \\
\text { maupun makanan untuk ternak } \\
\text { menthok, serta cangkang keong } \\
\text { yang bisa didaur ulang dijadikan }\end{array}$ \\
\hline
\end{tabular}




\begin{tabular}{|c|c|c|c|}
\hline & & & $\begin{array}{l}\text { sovenir pariwisata. } \\
\text { 8. Pencemaran udara akibat aktivitas } \\
\text { pabrik ikan. }\end{array}$ \\
\hline 2 & Sidomulyo & $\begin{array}{l}\text { 1. Pertanian } \\
\text { a. Padi } \\
\text { b. Kedelai } \\
\text { c. Jagung } \\
\text { d. Jeruk } \\
\text { 2. Peternakan } \\
\text { a. Sapi } \\
\text { b. Kambing }\end{array}$ & $\begin{array}{l}\text { 1. Hasil pertanian di sawah rawa } \\
\text { hanya bisa sekali panen. } \\
\text { 2. Terdapat masyarakat yang belum } \\
\text { memiliki jamban pribadi. } \\
\text { 3. Akses jalan utama desa sudah } \\
\text { baik, namun pada jalan dusun } \\
\text { masih bertekstur makadam. } \\
\text { 4. Terjadi pencemaran air sungai } \\
\text { dikarenakan limbah pabrik gula. } \\
\text { 5. Posisi dusun yang dekat dengan } \\
\text { sungai rawan terkena banjir. } \\
\text { 6. Tingkat pendidikan masih dalam } \\
\text { lulusan SD-SMP. } \\
\text { 7. Penyakit yang sering dikeluhkan } \\
\text { oleh masyarakat adalah lambung. }\end{array}$ \\
\hline 3 & Balekambang & $\begin{array}{l}\text { 1. Pertanian } \\
\text { a. Padi } \\
\text { b. Kedelai } \\
\text { c. Jagung } \\
\text { d. Jeruk } \\
\text { 2. Peternakan } \\
\text { a. Sapi } \\
\text { b. Kambing }\end{array}$ & $\begin{array}{l}\text { 1. } \begin{array}{l}\text { Tingkat pendidikan masih dalam } \\
\text { lulusan SD-SMP. }\end{array} \\
\text { 2. Penyakit yang sering dikeluhkan } \\
\text { oleh masyarakat adalah lambung } \\
\text { dan darah tinggi. } \\
\text { 3. Jalan yang berstatus sebagai jalan } \\
\text { provinsi masih terealisasi 270m } \\
\text { belum ada kejelasan selanjutnya. } \\
\text { 4. Aktivitas peternakan masih } \\
\text { menggunakan cara konvensional } \\
\text { perlu adanya bimbingan dan lahan } \\
\text { dalam mengembangkan aktrivitas } \\
\text { peternakan. }\end{array}$ \\
\hline 4 & Paseban & $\begin{array}{l}\text { 1. Pertanian } \\
\text { a. Padi } \\
\text { b. Semangka } \\
\text { c. Jagung } \\
\text { 2. Peternakan } \\
\text { a. Sapi }\end{array}$ & 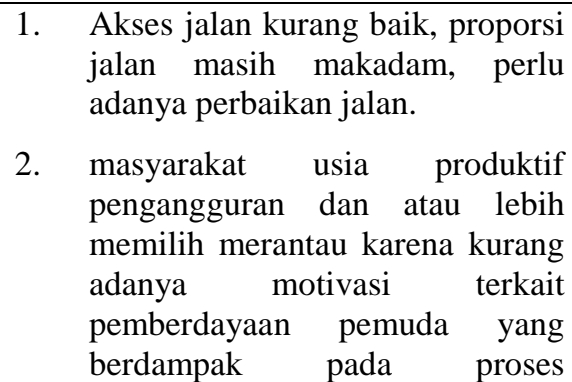 \\
\hline
\end{tabular}




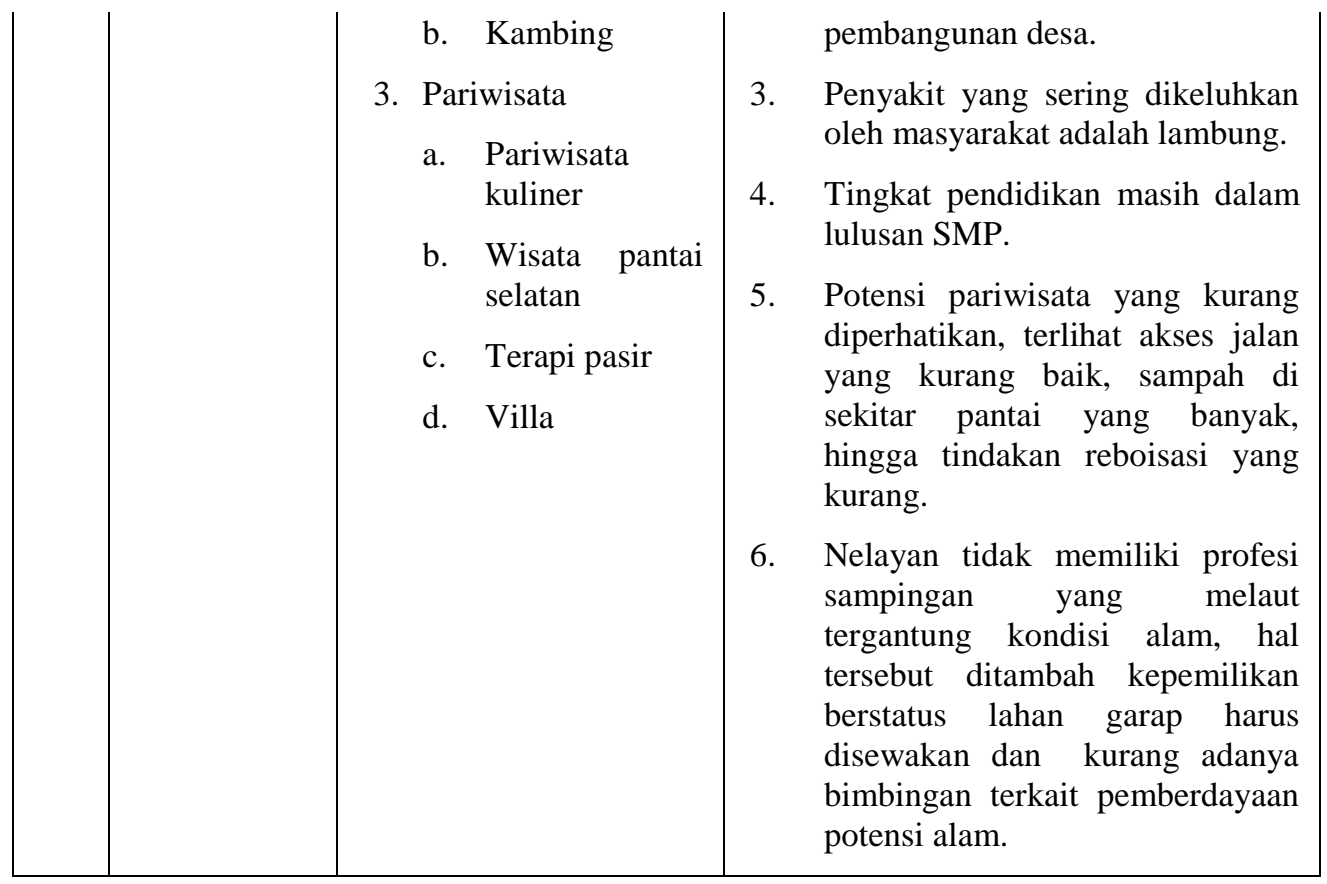

Potensi berasal dari bahasa latin yaitu potentia yang artinya kemampuan. Potensi adalah kemampuan yang mempunyai kemungkinan untuk dikembangkan (Ensiklopedi Indonesia, 1997:358). Potensi adalah kemampuan, kekuatan, kesanggupan, daya yang mempunyai kemungkinan untuk dikembangkan13. Dalam kamus ilmiah, potensi diartikan sebagai kekuatan, kesanggupan, kemampuan, kekuatan, pengaruh, daya dan kefungsian (Hamid, tt:504). Berdasarkan teori tersebut, pada dasarnya Desa Paseban mempunyai potensi yang sangat bagus untuk dikembangkan. Hal ini bisa dilakukan melalui pemberdayaan pengetahuan di perpustakaan desa.

Adapun pemberdayaan pengetahuan pada Perpustakaan Desa Paseban, Kecamatan Kencong, Kabupaten Jember melalui Empowerment. Empowerment (pemberdayaan masyarakat) adalah konsep pembangunan ekonomi yang merangkum nilai-nilai sosial dan mencerminkan paradigma baru dalam pembangunan yang bersifat people centered participatory, empowering and sustainable (Chambers, 1995 dalam Noor, 2011:94). Upaya untuk memberdayakan masyarakat (empowering) dapat dikaji dari 3 (tiga) aspek: a) Enabling, Enabling merupakan bagaimana cara perpustakaan desa atau pemerintah desa untuk menciptakan suasana yang memungkinkan potensi masyarakat dapat berkembang. Hal ini terkait bagaimana potensi setiap individu dimunculkan. Berikut hasil wawancara mengenai enabling. b) Empowering, Empowering merupakan bagaimana cara perpustakaan 
desa/pemerintah desa untuk memperkuat potensi yang dimiliki masyarakat melalui langkah-langkah nyata yang menyangkut penyediaan berbagai masukan dan pembukaan dalam berbagai peluang yang membuat masyarakat semakin berdaya. Adapun upayanya dengan (1) meningkatkan taraf pendidikan, (2) derajat kesehatan, (3) akses ke dalam sumber-sumber kemajuan ekonomi (modal, teknologi, informasi, lapangan kerja, dan pasar, dan (4) pembangunan sarana dan prasarana. Berikut hasil wawancara mengenai empowering. c) Protecting, Protecting merupakan bagaimana perpustakaan desa atau pemerintah desa dalam melindungi dan membela kepentingan masyarakat lemah. Berikut hasil wawancara mengenai protecting.

Berdasarkan hasil wawancara dapat disimpulkan bahwa pada dasarnya Pemerintah Desa Paseban sudah pernah melaksanakan pemberdayaan terkait pembangunan wisata, BumDes, dan melalui penyediaan internet. Akan tetapi, tidak di bawah naungan perpustakaan desa. Pemberdayaan yang dilakukan bersifat parsial, tidak terpusat pada perpustakaan desa. Terkait dengan tiga aspek pemberdayaan, Pemerintah Desa Paseban belum memenuhi tiga aspek tersebut.

Model pengembangan pemberdayaan pengetahuan pada Perpustakaan Desa Paseban, Kecamatan Kencong, Kabupaten Jember yaitu : a) Layanan Perpustakaan Desa, Berdasarkan hasil wawancara dan observasi dapat disimpulkan bahwa terdapat layanan perpustakaan desa. Berikut layanan perpustakaan yang ada di Perpustakaan Desa Paseban: 1) Layanan perpustakaan bersifat bebas, bisa mulai pukul $12.00-03.00$ (15 jam) atau bahkan di saat tertentu bisa 24 jam. 2) Layanan perpustakaan ditujukan atau hak pakai oleh karang taruna bukan untuk masyarakat umum. 3) Secara formal, perpustakaan merupakan tanggung jawab PKK di bawah naungan Ka. Ur Tata Usaha dan Umum, akan tetapi secara informal menjadi tanggung jawab karang taruna. 4) Terdapat layanan music, tapi hanya untuk anggota karang taruna. 5) Layanan wifi yang diperuntukkan masyarakat umum. 6) Layanan perpustakaan desa belum berfungsi sebagai pusat informasi atau pusat pengetahuan, hanya sebagai tempat untuk berkumpulnya karang taruna sebagai tempat dalam mengagendakan rapat. 7) Layanan perpustakaan desa tidak dipegang oleh pustakawan atau bahkan petugas perpustakaan.

Perpustakaan merupakan sarana penyedia informasi dan pelestarian peradaban manusia yang dapat dijadikan sebagai media pendidikan, penelitian, pengabdian masyarakat, komunikasi ilmiah antargenerasi dan lainnya (Paijo, 2006:13). Sehingga layanan perpustakaan desa harus mengacu pada hal tersebut. 
Model pengembangan pemberdayaan pengetahuan pada Perpustakaan Desa berdasarkan hasil wawancara menunjukkan bahwa pemberdayaan di Desa Paseban sudah dilakukan akan tetapi bersifat parsial, tidak terpusat pada naungan perpustakaan desa. Berikut pemberdayaan yang pernah dilakukan oleh Pemerintah Desa Paseban: 1) Menanam pohon pisang yang dititipkan dari pemerintah desa untuk ditanam di depan rumah warga. 2) Karang taruna memberikan les gratis untuk anak SD. 3) Karang taruna sendiri juga melakukan uji coba berdasarkan buku yang ada di perpustakaan, misalnya beternak angkrang yang untuk obat, sapi, dan lain-lain. 4) Pengembangan internet. 5) Karang taruna mempunyai kegiatan terkait penggalian dana. 6) Karang taruna merupakan wadah bagi anak muda dalam hal pramuka dan silat. 7) Karang taruna sebagai wadah terkait penjualan hasil pertanian masyarakat. 8) Event besar/hardiknas melaksanakan kegiatan kesenian anak (seni musik). 9) Karang Taruna menerima KKN dari Universitas Muhammadiyah Jember yang mengajukan pengabdian untuk memberikan les gratis/bimbel untuk siswa kelas $6 \mathrm{SD} / \mathrm{MI}$ di perpustakaan desa. Akan tetapi, diarahkan pada tempat yang lebih memungkinkan di Sekretariat Koperasi Masjid yang dijadikan taman baca/perpustakaan. Adapun pelaksanaannya 3 sampai 4 bulan. 10) Penyuluhan terkait tanaman untuk pembibitan yang dilakukan oleh PT Eswes. 11) penyuluhan dari Dinas Pertanian dan dikasih obat untuk pertanian secara gratis. 12) Penyuluhan dari Dinas perkebunan.

Empowerment (pemberdayaan masyarakat) adalah konsep pembangunan ekonomi yang merangkum nilai-nilai sosial dan mencerminkan paradigma baru dalam pembangunan yang bersifat people centered participatory, empowering and sustainable (Chambers, 1995 dalam Noor, 2011:94). upaya untuk memberdayakan masyarakat (empowering) dapat dikaji dari 3 (tiga) aspek.

Enabling yaitu menciptakan suasana yang memungkinkan potensi masyarakat dapat berkembang. Asumsinya adalah pemahaman bahwa setiap orang, setiap masyarakat mempunyai potensi yang dapat dikembangkan artinya tidak ada orang atau masyarakat tanpa daya. Pemberdayaan adalah upaya untuk membanguna daya dengan mendorong, memotivasi dan membangkitkan kesadaran akan potensi yang dimiliki masyarakat serta upaya untuk mengembangkannya. Model Enabling Pada Pemberdayaan Pengetahuan di Perpustakaan Desa sebagai berikut : Perpustakaan Desa sebagai Pusat Pengetahuan; Perpustakaan Desa menciptakan suasana yang memungkinkan potensi masyarakat dapat berkembang dengan memaksimalkan fungsi perpustakaan. 
Paijo (2006:13) menjelaskan keberadaan perpustakaan merupakan bagian integral yang mendukung proses pengembangan msayarakat informasi. Di sinilah kemudian yang menyebabkan keberadaan perpustakaan semakin tidak terelakkan di tengah masyarakat. Perpustakaan ini juga mampu berfungsi sebagai salah satu upaya dalam melakukan kegiatan belajar serta memenuhi kebutuhan pendidikan dalam masyarakat melalui programprogram literasi informasi. Mengingat di era informasi, perkembangan ilmu pengetahuan dan informasi semakin pesat sehingga sering memunculkan permasalahan dalam pengelolaan informasi dari mulai pencarian, penemuan dan pemanfaatan informasi. Keberadaan perpustakaan yang representatif dalam jangka panjang dimaksudkan untuk 1. Menumbuhkembangkan minat baca tulis masyarakat. Masyarakat dapat memanfaatkan waktu untuk mendapat informasi di perpustakaan. Kebiasaan ini meningkatkan minat baca mereka. Kemudian dari banyak membaca dan kualitas bacaan yang pada akhirnya dapat menumbuhkan minat tulis. 2. Mengenalkan teknologi informasi.Perkembangan teknologi informasi harus terus diikuti oleh para pengelola perpustakaan komunitas. Untuk itu, perlu proses pengenalan dan penerapan teknologi informasi dari perpustakaan yang disesuaikan dengan kebutuhan masyarakat setempat. 3. Membiasakan akses informasi secara mandiri. Masyarakat perlu didorong dan diarahkan untuk memiliki rasa percaya diri dan mandiri untuk mengakses informasi. Hanya orang yang percaya diri dan mandirilah yang mampu mencapai kemajuan. 4. Memupuk bakat dan minat. Bacaan, tayangan gambar, dan musik di perpustakaan mampu menumbuhkan bakat dan minat seseorang. Melalui kegiatan yang variatif dalam layanan perpustakaan komunitas (TBM) akan memotivasi masyarakat untuk menemukan dan mengembangkan bakat dan potensi yang ada.

Upaya pemberdayaan sendiri adalah sebuah upaya untuk meningkatkan dan memandirikan masyarakat. Pemberdayaan masyarakat adalah upaya untuk menciptakan/meningkatkan kapasitas masyarakat, baik secara individu maupun berkelompok, dalam memecahkan berbagai persoalan terkait upaya peningkatan kualitas hidup, kemandirian, dan kesejahteraannya. Menurut Setiana (2002) dalam Lucie Setiana (2005: 5-6), pemberdayaan masyarakat sebenarnya mengacu pada kata empowerment, yaitu sebagi upaya untuk mengaktualisasikan potensi yang sudah dimiliki sendiri oleh masyarakat. Jadi, pendekatan pemberdayaan masyarakat titik beratnya adalah penekanan pada pentingnya masyarakat lokal yang mandiri sebagai suatu sistem yang mengorganisir diri mereka sendiri. Salah satu upaya yang dapat dilakukan dalam pemberdayaan masyarakat adalah melalui pengembangan perpustakaan komunitas, dimana dengan keberadaan sebuah 
perpustakaan diharapkan masyarakat akan meningkat literasinya dan dapat memanfaatkan informasi yang ada dalam pengembangan potensi yang ada diwilayahnya.

Empowering yaitu memperkuat potensi yang dimiliki masyarakat melalui langkah-langkah nyata yang menyangkut penyediaan berbagai input dan pembukaan dalam berbagai peluang yang akan membuat masyarakat semakin berdaya. Upaya yang paling pokok dalam empowerment ini adalah meningkatkan taraf pendidikan dan derajat kesehatan serta akses ke dalam sumber-sumber kemajuan ekonomi (modal, teknologi, informasi, lapangan keja, pasar) termasuk pembangunan sarana dan prasarana dasar seperti (irigasi, jalan, listrik, sekolah, layanan kesehatan) yang dapat dijangkau lapisan masyarakat paling bawah yang keberdayannya sangat kurang. Oleh karena itu diperlukan program khusus, karena programprogram umum yang berlaku untuk semua tidak selalu menyentuh kepentingan lapisan masyarakat seperti ini. Model Empowering Pada Pemberdayaan Pengetahuan di Perpustakaan Desa sebagai berikut : Memperkuat Perpustakaan Desa sebagai Pusat Pengetahuan. Memperkuat Perpustakaan Desa dalam menciptakan suasana yang memungkinkan potensi masyarakat dapat berkembang dengan memaksimalkan fungsi perpustakaan dengan langkah-langkah nyata. Konsep yang ada pada enabling dipraktikkan dengan langkah-langkah nyata dan tersedianya sarana prasarana yang dapat mendukung terciptanya pemberdayaan pada masyarakat.

Protecting yaitu melindungi dan membela kepentingan masyarakat lemah. Untuk meningkatkan partisipasi masyarakat dalam proses pengambilan keputusan yang menyangkut diri dan masyarakatnya merupakan unsur penting, sehingga pemberdayaan masyarakat sangat erat hubungannya dengan pementapan, pembudayaan dan pengalaman demokrasi (Friedmann, 1994 dalam Noor, 2011:95). Model Protecting Pada Pemberdayaan Pengetahuan di Perpustakaan Desa sebagai berikut : Perpustakaan Desa sebagai Pusat Pengetahuan mendirikan juga pusat informasi yang dapat melindungi dan membela masyarakat dalam hal pengetahuan dan informasi terkait pendistribusian hasil inovasi masyarakat. Perpustakaan Desa mengcover segala hal yang dibutuhkan masyarakat dalam mengembangkan literasi kesejahteraan.

\section{KESIMPULAN}

Kondisi eksisting Perpustakaan Desa Paseban, Kecamatan Kencong, Kabupaten Jember. a) Gambaran umum lokasi (bentuk, ukuran dan kondisi fisik) yaitu Perpustakaan Desa Paseban berbentuk ruang persegi dengan satu 
ruangan, Ukuran $=3 \times 4 \mathrm{~m}^{2}$, Kondisi fisik = dalam keadaan baik, hanya saja kurang terjaga kebersihannya. Ditemukan sisa rokok di dalam ruangan. b) Kondisi lingkungan yaitu kondisi lingkungan Balai Desa Paseban termasuk dalam keadaan baik. Sebelah kanan, kiri, depan, dan belakang merupakan rumah warga. Hal ini termasuk juga dengan kondisi potensi dari Desa Paseban itu sendiri. c) Batas-batas yaitu batas-batas perpustakaan 1) Sebelah kiri ruang sekretariat, 2) Sebelah kanan ruang aula, 3) Sebelah depan balai desa, warung, mushola, 4) Rencana: depan perpustakaan akan dijadikan taman baca. d) Potensi yaitu potensi desa Paseban cukup beragam mulai dari pertanian, peternakan dan pariwisata. Desa Paseban merupakan salah satu desa yang mempunyai potensi tinggi di Kabupaten Jember. Wilayahnya yang dekat dengat pantai merupakan kelebihan tersendiri yang dapat dijadikan sebagai sumber destinasi wisata dan juga sebagai sumber produksi ikan laut. Selain itu, pada dasarnya Desa Paseban mempunyai potensi yang sangat tinggi di bidang pertanian/sawah, ladang/tegalan, serta perikanan darat/tawar. Bidang pertanian/sawah dan ladang/tegalan, masyarakat menanam berbagai jenis tanaman yang bervariasi, dari mulai polowijo sampai buah, bahkan umbi-umbian. Sedangkan dari bidang perikanan, untuk perikanan air tawar banyak masyarakat yang membuat tambak-tambak, baik tambak di rumah maupun tambak yang dibangun di area dekat persawahan. Adapun produk perikanan air tawar, antara lain: gurami, lele, mujair, dan banyak lagi. Terdapat pula potensi perikanan air payau.

Pemberdayaan pengetahuan pada Perpustakaan Desa Paseban, Kecamatan Kencong, Kabupaten Jember. a) Enabling, b) Empowering, c) Protecting.

Dasarnya pemerintah desa Paseban sudah pernah melaksanakan pemberdayaan terkait pembangunan wisata, BumDes, dan melalui penyediaan internet. Akan tetapi, tidak di bawah naungan perpustakaan desa. Pemberdayaan yang dilakukan bersifat parsial, tidak terpusat pada perpustakaan desa. Terkait dengan tiga aspek pemberdayaan, Pemerintah Desa Paseban belum memenuhi tiga aspek tersebut.

Model pengembangan pemberdayaan pengetahuan pada Perpustakaan Desa Paseban, Kecamatan Kencong, Kabupaten Jember. a) Layanan Perpustakaan Desa, Perpustakaan merupakan sarana penyedia informasi dan pelestarian peradaban manusia yang dapat dijadikan sebagai media pendidikan, penelitian, pengabdian masyarakat, komunikasi ilmiah antargenerasi dan lainnya. Layanan perpustakaan Desa Paseban belum memenuhi hal tersebut dengan baik. b) Model pengembangan pemberdayaan pengetahuan pada Perpustakaan Desa. 
Model enabling pada pemberdayaan pengetahuan di perpustakaan desa sebagai berikut : a) Perpustakaan Desa sebagai Pusat Pengetahuan, b) Perpustakaan Desa menciptakan suasana yang memungkinkan potensi masyarakat dapat berkembang dengan memaksimalkan fungsi perpustakaan.

Model empowering pada pemberdayaan pengetahuan di perpustakaan desa sebagai berikut : a) Memperkuat Perpustakaan Desa sebagai Pusat Pengetahuan, b) Memperkuat Perpustakaan Desa dalam menciptakan suasana yang memungkinkan potensi masyarakat dapat berkembang dengan memaksimalkan fungsi perpustakaan dengan langkahlangkah nyata. Konsep yang ada pada enabling dipraktikkan dengan langkahlangkah nyata dan tersedianya sarana prasarana yang dapat mendukung terciptanya pemberdayaan pada masyarakat.

Model protecting pada pemberdayaan pengetahuan di perpustakaan desa sebagai berikut : a) Perpustakaan Desa sebagai Pusat Pengetahuan mendirikan juga pusat informasi yang dapat melindungi dan membela masyarakat dalam hal pengetahuan dan informasi terkait pendistribusian hasil inovasi masyarakat. b) Perpustakaan Desa meng-cover segala hal yang dibutuhkan masyarakat dalam mengembangkan literasi kesejahteraan.

\section{DAFTAR RUJUKAN}

Arifin, Alvin, et. Al., Pengaruh Pemberdayaan dan Motivasi terhadap Kinerja Karyawan. Jurnal Administrasi Bisnis, Malang, Vol. 8, No. 2, 2014, hal.,

3.http://administrasibisnis.studentjournal.ub.ac.id/index.php/jab/articl e/view/358

Budiman dan Riyanto, Agus. 2013. Kapita Selekta Kuesioner Pengetahuan dan Sikap dalam Penelitian Kesehatan. Jakarta: Salemba Medika

Creswell, J. W. 2015. Penelitian Kualitatif dan Desain Riset:memilih di antara lima pendekatan. Edisi Ketiga. Dialihbahasakan oleh Ahmad Lintang Lazuardi Pustaka Pelajar: Yogyakarta. . 2016. Research Design: Pendekatan Metode Kualitatif, Kuantitatif, dan Campuran. Edisi Keempat. Dialihbahasakan oleh Achmad Fawaid dan Rianayati Kusmini Pancasari. Pustaka Pelajar: Yogyakarta.

Darmono. Manajemen Pelayanan Perpustakaan Desa. Makalah disampaikan pada Kegiatan Koordinasi Pengembangan Budaya Baca - Bimtek Kader Pustaka se Kabupaten Malang Tahun 2016 Tanggal 25 s/d 26 
Mei 2016 di Hotel Fariz - Malang. http://lib.um.ac.id/wpcontent/uploads/2017/03/Makalah-Manajemen-Pelayanan-

\section{Perpustakaan}

Ensiklopedi Indonesia. 1997. Departemen Pendidikan dan Kebudayaan. Jakarta: Pakhi Pamungkas.

Hamid, Farida. tt. Kamus Ilmiah Populer Lengkap. Surabaya: Apollo.

Setiana, Lucie. 2005. Teknik Penyuluhan dan Pemberdayaan Masyarakat. Ghalia. Indonesia: Bogor

Menteri Dalam Negeri dan Otonomi Daerah. 2001. Keputusan Menteri dalam Negeri dan Otonomi Nomor 3 Tahun 2001 tentang Penyelenggaraan Perpustakaan Desa/Kelurahan.

Noor, Munawar. Pemberdayaan Masyarakat. Jurnal Ilmiah CIVIS, Volume I, No 2, Juli 2011. http://journal.upgris.ac.id/index.php/civis/article/download/591/541

Notoatmodjo, S. 2012. Promosi Kesehatan dan Perilaku Kesehatan. Jakarta: Rineka Cipta.

Paijo, Y. 2006."Perpustakaan". Dalam Media Informasi, Vol. XV no.3 Th.2006

Perpustakaan Nasional RI. 2011. Standar Perpustakaan Desa/kelurahan SNP 005:2011. Jakarta: Perpustakaan Nasional RI, 2011. 